



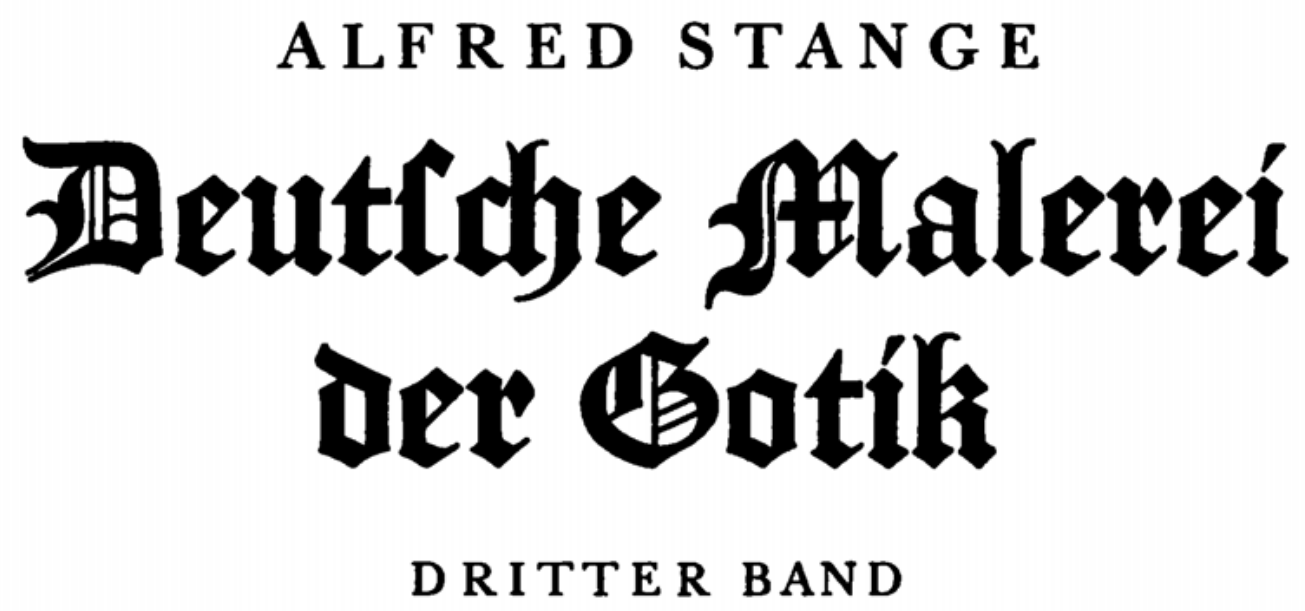

NORDDEUTSGHLAND IN DER ZEIT

VON 1400 BIS 1450

画eutfdher 泫unftuerlag ßerlín 1938 
Druck des Textes Walter de Gruyter \& Co., Berlin, dea Bilderteiles Sinsel \& Co., Leipzig 


\section{解 Clemen}

in Dankbarkeit und Verehrung 
